METALLURGY AND FOUNDRY ENGINEERING - Vol. 37, 2011, No. 2

Piotr Chyła**, Aneta Łukaszek-Sołek*, Sylwia Bednarek*, Paweł Chyła**

\title{
CLOSED DIE FORGING OF TURBINE DISC TO FIX BLADES FROM INCONEL ${ }^{\circledR} 718$
}

\section{INTRODUCTION}

In recent years there has been an increasing interest in nickel superalloys as the heatresisting and high-temperature alloys [1]. In comparison with steels, they exhibit much better corrosion resistance and long-term resistance at temperatures above $650{ }^{\circ} \mathrm{C}$, while maintaining good plasticity at low temperatures [2]. Nickel superalloys are used in turbo and turbine aircraft engines, gas turbines for energetics, on rotors, blades, steam turbines and propelling nozzles, in automotive, chemical, petrochemical and many other industries. Nickel Superalloys can be produced by means of conventional metallurgy and powder metallurgy [3, 4]. The most popular and most widely used representative of this group of materials is the alloy known under the trade name Inconel ${ }^{\circledR} 718$.

The alloy was developed by a U.S. firm International Nickel Company (INCO) in 1959. GE Aviation became interested in the alloy and used it for manufacturing engine parts for GE-1 and GE-4 engine series. Currently, the alloy is one of the most widely used construction material for aircraft engine turbine blades. Table 1 shows the limiting chemical composition of the alloy used in the study.

Table 1. Chemical composition of Inconel ${ }^{\circledR} 718, \%[5]$

\begin{tabular}{|c|c|c|c|c|c|c|c|}
\hline $\mathrm{C}$ & $\mathrm{Ni}$ & $\mathrm{Fe}$ & $\mathrm{Cr}$ & $\mathrm{Nb}$ & $\mathrm{Mo}$ & $\mathrm{Ti}$ & $\mathrm{Al}$ \\
\hline 0.04 & 52.5 & 18.5 & 19 & 5 & 3 & 1 & 0.5 \\
\hline
\end{tabular}

Inconel ${ }^{\circledR} 718$ has excellent creep and fatigue strengths, and good corrosion resistance at high temperatures. It has superior weldability and very good mechanical properties. It is

* Ph.D., ** M.Sc.: AGH University of Science and Technology, Faculty of Metals Engineering and Industrial Computer Science, Krakow, Poland; e-mail: pichyla@metal.agh.edu.pl 
used for manufacturing components working in aggressive gas environments and even at temperatures exceeding $1000{ }^{\circ} \mathrm{C}$. Products made of it include engine's hot section blades, disks, shafts and housings [6,7]. Products from this alloy are manufactured using three methods: casting, powder metallurgy methods, and plastic working.

\section{NUMERICAL CALCULATIONS}

Boundary conditions were chosen in this way to check the behavior of the material in a typical forging temperatures (upper and lower range). The other process parameters (tools temperature, friction, deformation size in upsetting operation) were changed to determine the most favorable conditions to carry out the real process.

In the paper simulations of turbine disk forging process for attaching blades produced from Inconel ${ }^{\circledR} 718$ were carried out (Fig. 1). The process was carried out for several alternative variants, as described in Figure 2. For the hydraulic press cross-bar speed constant value of $10 \mathrm{~mm} / \mathrm{s}$ was assumed in all the cases examined. In the calculations initial batch sizes taking into account losses on the excessive flash and scale were assumed: $H_{0}=600 \mathrm{~mm}$ and $D_{0}=530 \mathrm{~mm}$.

a)

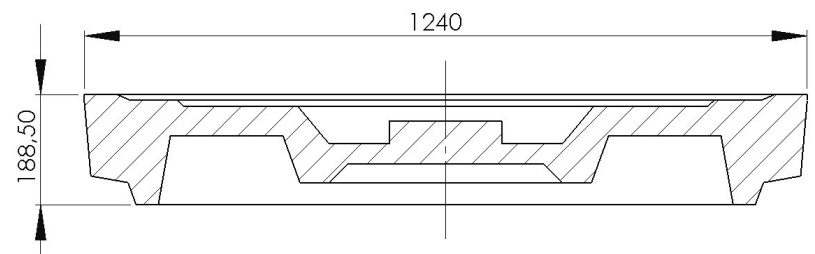

b)

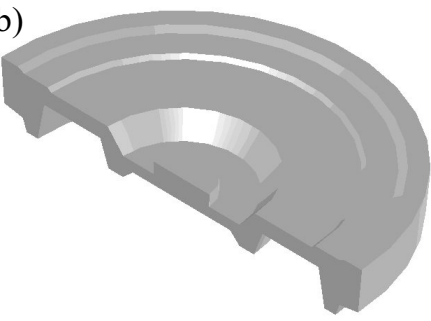

Fig. 1. Basic dimensions (a) and half-view of the turbine disc forging (b)

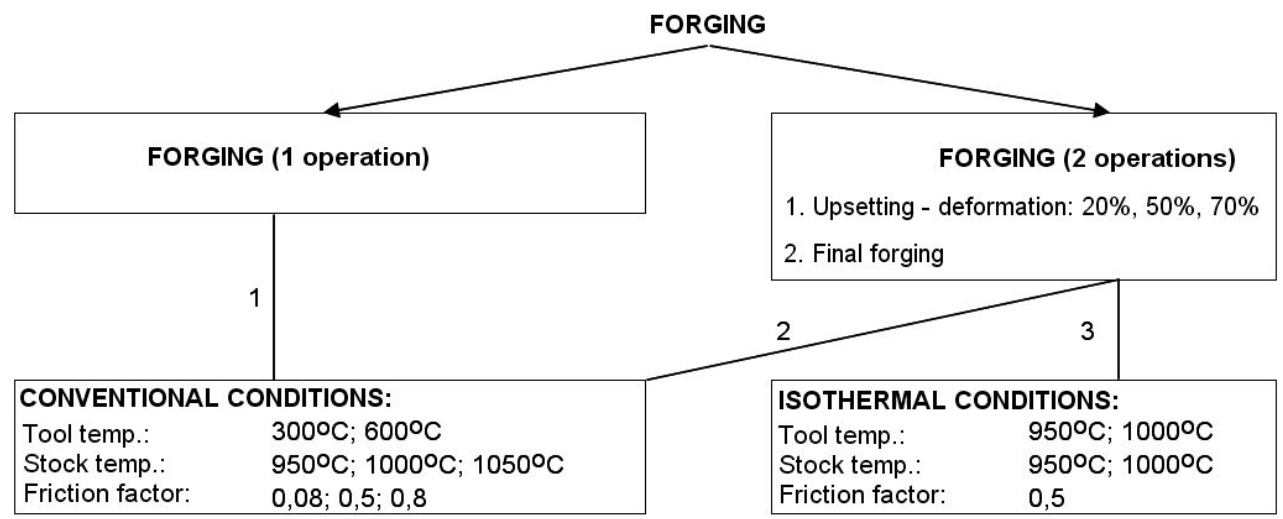

Fig. 2. Diagram of simulations performed, 1,2,3-variants of calculations 


\subsection{One-stage forging}

One-stage forging (Variant 1) was performed for two different values of tool temperature, three temperatures of stock and three kinds of lubricants with different tribological characteristics. For this technology - forging directly from the stock (Fig. 3) - in all of the variants analyzed forging laps occurred. Sample mean stress distributions in forgings forged in the initial temperature of $1050{ }^{\circ} \mathrm{C}$ together with the indication of areas where the laps occurred, are shown in Figure 4.

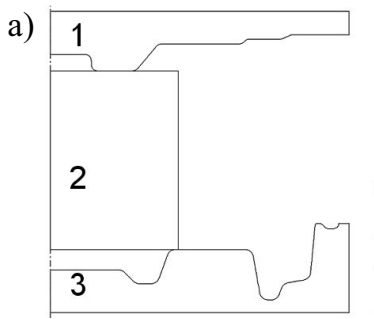

\section{b)}

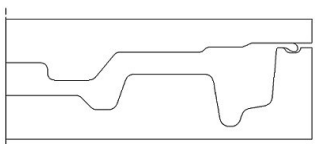

Fig. 3. The beginning (a) and end (b) of one-stage turbine disc forging process: 1 - upper die, 2 -stock, 3 - lower die

Friction

factor

Tool Temperature $300{ }^{\circ} \mathrm{C}$
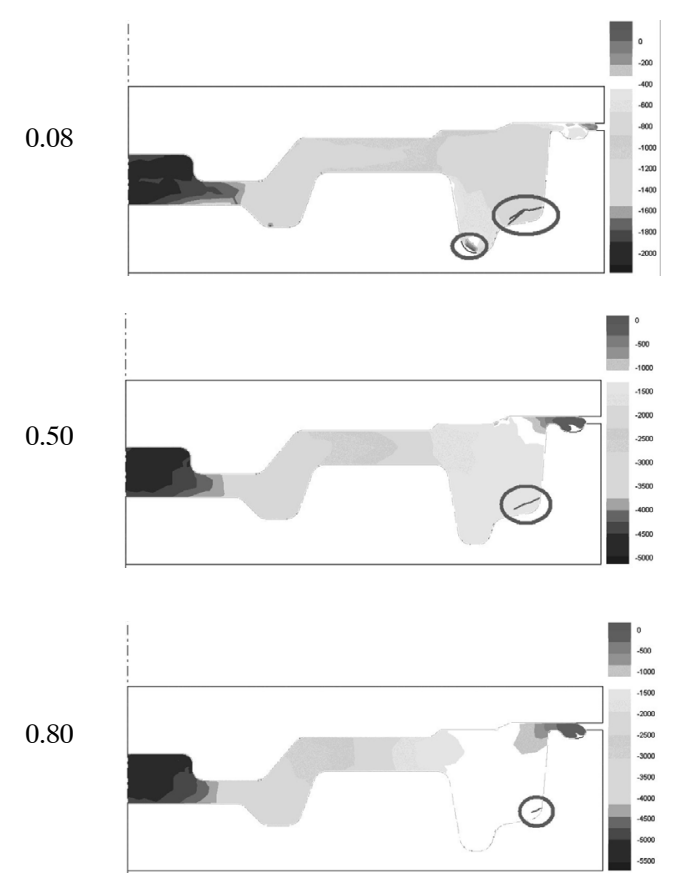

Tool Temperature $600{ }^{\circ} \mathrm{C}$
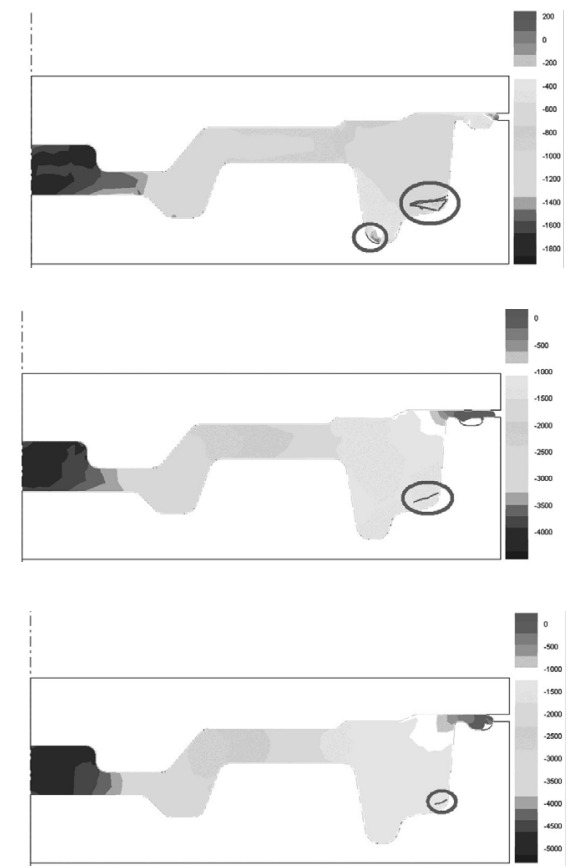

Fig. 4. Mean stress distribution with laps view in forging of turbine disc made from the stock with initial temperature of $1050{ }^{\circ} \mathrm{C}$ 
Mean stress distribution is a parameter by which we can predict tool wear. The resulting distributions also inform us about the indirect effects of deformed material temperature, deformation and material flow.

On the basis of strength value in the last stage of forging the results of numerical calculations were used to evaluate the influence of lubrication conditions and tool temperature on the process of forming (Fig. 5). Verification was based on all the analyzed variants of forging.

a)

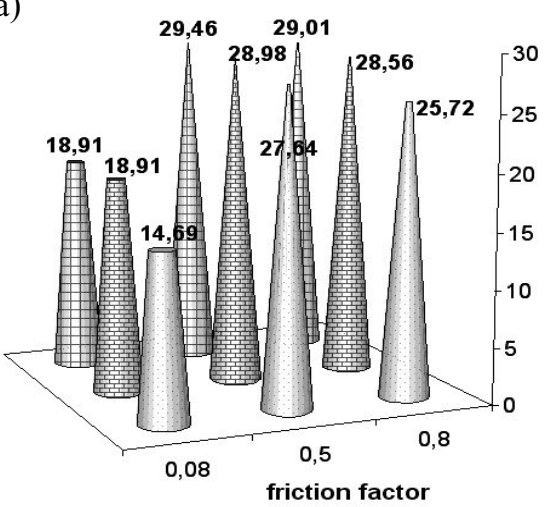

b)

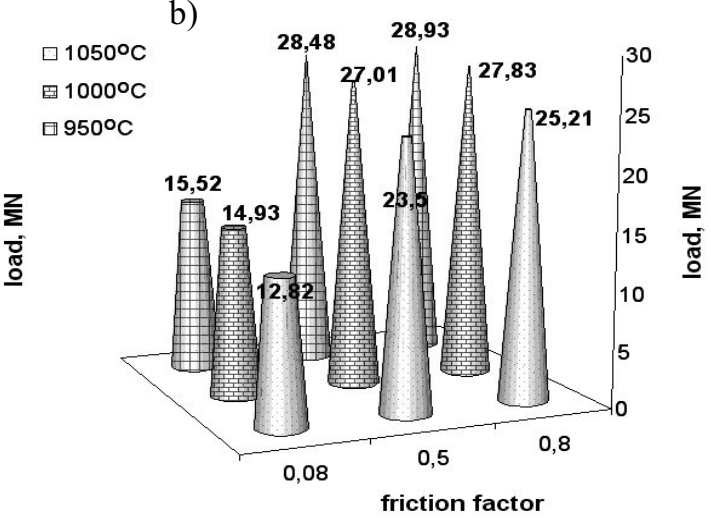

Fig. 5. Load values $(M N)$ in final stage of forming with the tools temperature $300^{\circ} \mathrm{C}(a)$ and $600{ }^{\circ} \mathrm{C}(\mathrm{b})$

\subsection{Two-stage forging}

Two-stage forging in conventional conditions was performed for the corresponding stock and tool temperature, and lubricants (Variant 2). For this technology (Fig. 6) draft $(20 \%, 50 \%$ and $70 \%)$ during upsetting in the first treatment was investigated too.

a)
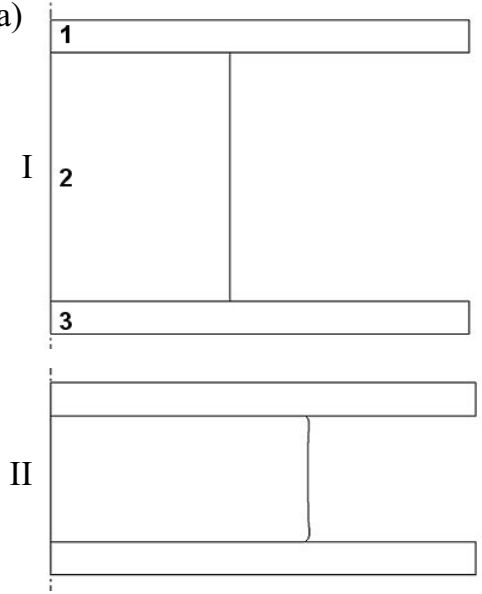

b)
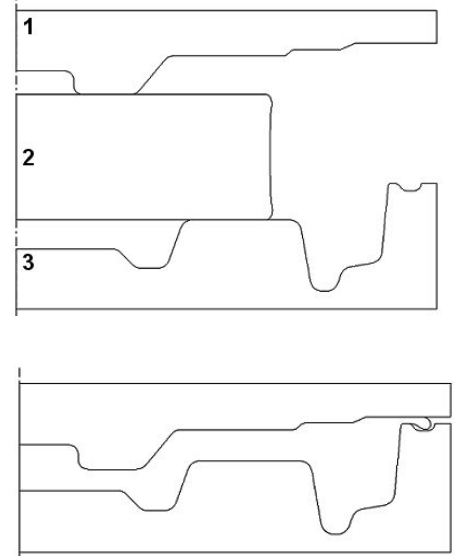

Fig. 6. The beginning (a) and end (b) of the two-stages process: I-upsetting, II-forging: 1 -upper die, 2 -stock, 3 - lower die 
The parameters for which from technological point the turbine disc to fix blades has obtained satisfactory results are: the graphite-glass lubricant $(\mathrm{m}=0.08)$, draft in the first treatment equal to $50 \%$, and all three temperatures to which the stock was heated: $950{ }^{\circ} \mathrm{C}$, $1000{ }^{\circ} \mathrm{C}$ and $1050{ }^{\circ} \mathrm{C}$. The only variant of numerical calculations rejected was the one in which the temperature was set to $1050{ }^{\circ} \mathrm{C}$ for the stock and $300{ }^{\circ} \mathrm{C}$ for the tools. Sample mean stress distributions for these cases are shown in Figure 7.

Stock temperature

Tool Temperature $300{ }^{\circ} \mathrm{C}$
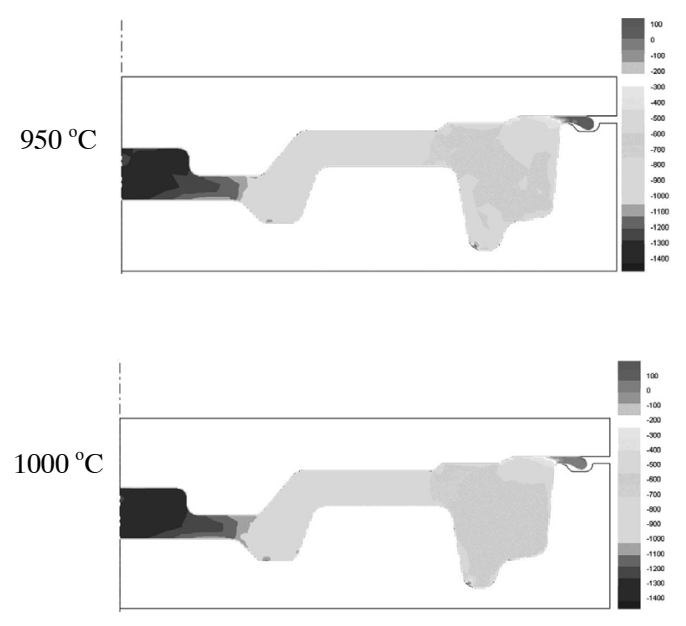

$1050{ }^{\circ} \mathrm{C} \quad$ Variant rejected because of laps formation
Tool Temperature $600{ }^{\circ} \mathrm{C}$
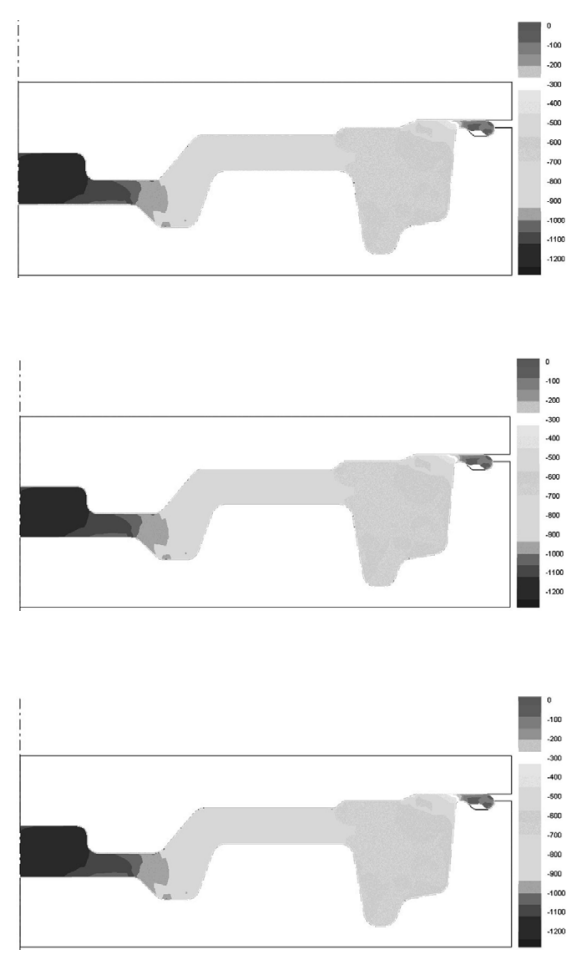

Fig. 7. Mean stress distribution in forging of turbine disc made in two-stage process

Maximum load values obtained in the second stage of turbine disk forging under conventional conditions are summarized in Table 2. The most favourable results were obtained in case of forging with lubricant with the lowest friction factor, taking into account the $50 \%$ draft of initial upsetting. For those cases in the process of one-stage forming we observe substantially lower loads in comparison with the other variants. In other cases, both the friction and the initial draft do not affect in such a significant way the obtained load values.

Two-stage forging under isothermal conditions was performed for two temperatures of stock and tools $950{ }^{\circ} \mathrm{C}$ and $1000{ }^{\circ} \mathrm{C}$ and lubricant with intermediate friction factor (option 3). 
Moreover, for this technology (Fig. 6) draft during upsetting in the first stage was investigated. For this technology the variants that meet the technological requirements were:

- two-stage forging from $50 \%$ draft in the first operation, at $950{ }^{\circ} \mathrm{C}$,

- two-stage forging from $70 \%$ draft in the first operation, at $1000{ }^{\circ} \mathrm{C}$.

Table 2. Maximum load values obtained in the second stage of forging

\begin{tabular}{|c|c|c|c|c|c|c|}
\hline \multirow{2}{*}{$\begin{array}{c}\text { Variable } \\
\text { parameters }\end{array}$} & \multicolumn{5}{|c|}{ Tool temperature, ${ }^{\circ} \mathrm{C}$} \\
\cline { 2 - 7 } & \multicolumn{7}{|c|}{300} & \multicolumn{7}{c|}{600} \\
\cline { 2 - 7 } & 0.08 & 0.50 & 0.80 & 0.08 & 0.50 & 0.80 \\
\cline { 2 - 7 } & \multicolumn{7}{|c|}{ Maximum load values, MN } \\
\hline Draft, \% & \multicolumn{7}{|c|}{ Stock temperature $950{ }^{\circ} \mathrm{C}$} \\
\hline 70 & 27.55 & 26.77 & 27.57 & 21.84 & 26.55 & 26.98 \\
\hline 50 & 10.13 & 26.04 & 28.00 & 9.99 & 24.03 & 27.43 \\
\hline 20 & 27.62 & 28.07 & 28.64 & 22.74 & 27.06 & 28.74 \\
\hline Draft, \% & \multicolumn{7}{|c|}{ Stock temperature $1000{ }^{\circ} \mathrm{C}$} \\
\hline 70 & 24.97 & 26.77 & 27.57 & 21.84 & 26.55 & 27.26 \\
\hline 50 & 9.98 & 26.04 & 28.00 & 9.99 & 24.03 & 27.61 \\
\hline 20 & 27.62 & 28.07 & 28.64 & 22.74 & 27.06 & 27.78 \\
\hline Draft, \% & & & \multicolumn{7}{|c|}{ Stock temperature $1050{ }^{\circ} \mathrm{C}$} \\
\hline 70 & 24.97 & 26.77 & 27.57 & 21.84 & 26.55 & 26.78 \\
\hline 50 & 19.93 & 26.04 & 28.00 & 9.99 & 24.03 & 23.19 \\
\hline 20 & 27.62 & 28.07 & 28.64 & 22.74 & 27.06 & 25.11 \\
\hline
\end{tabular}

In the remaining simulations forging laps and excessive mean stresses occurred, which eliminate these variants from the production process. For this reason they are not included in further analysis. Figure 8 shows the mean stress distribution in forgings that meet the technological requirements (i.e. no laps).

The loads in the die impression obtained in the above described isothermal forging technologies are respectively $-21.63 \mathrm{MN}$ for the forging at $950{ }^{\circ} \mathrm{C}$ and $18.98 \mathrm{MN}$ for forging at $1000^{\circ} \mathrm{C}$. Mean stress values obtained from the calculations greatly exceed the limit values (limit value taking into account the strength of the tools - $2000 \mathrm{MPa}$ [8]). It would be advisable to think of introducing further modifications to the process or using tools made from special materials. Legitimate bill of costs which includes the number of produced pieces, availability of equipment, material cost, etc. is a necessary condition. 
a)

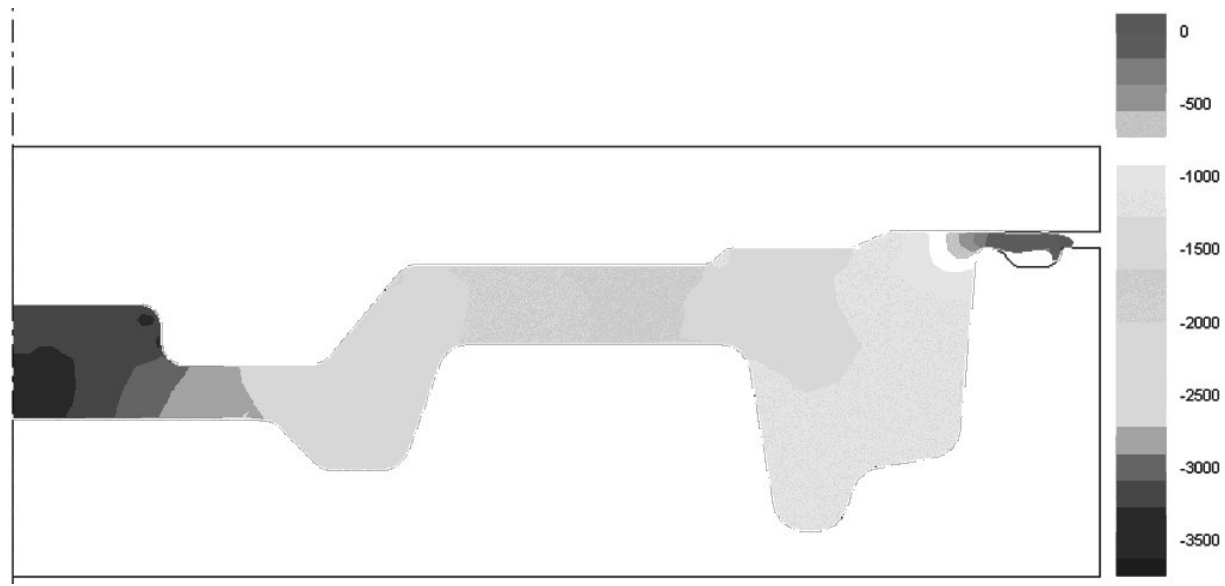

b)

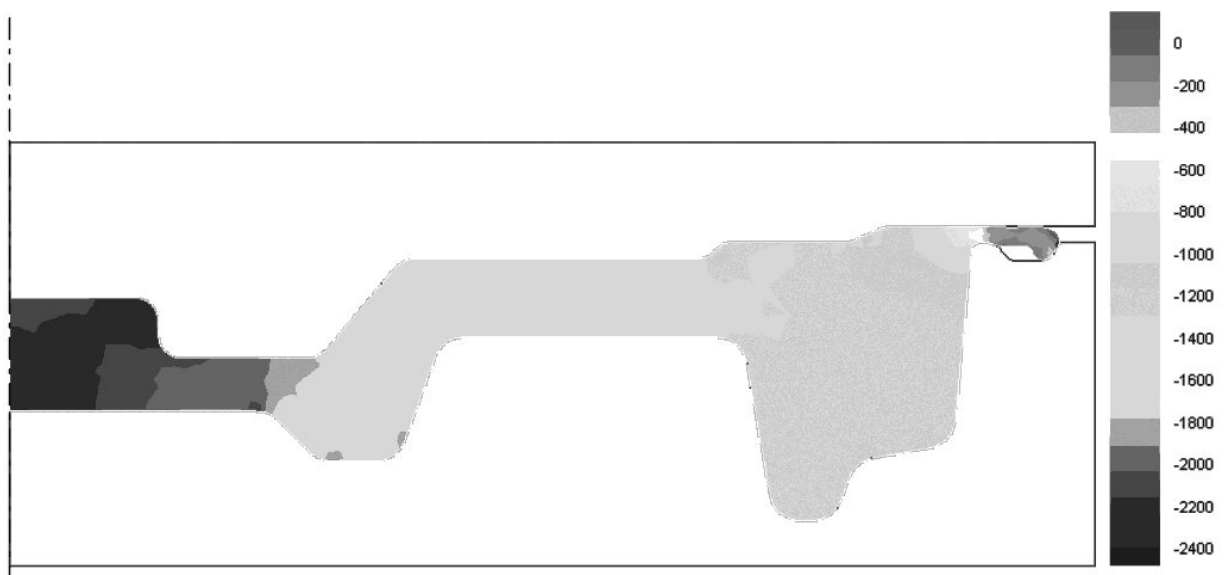

Fig. 8. Mean stress distribution in forgings of turbine disc made in isothermal conditions: a) $950{ }^{\circ} \mathrm{C}$, $m=0.5,50 \%$ draft; b) $1000{ }^{\circ} \mathrm{C}, m=0.5,70 \%$ draft

\section{SUMMARY AND CONCLUSIONS}

The first technology was to obtain a forging in one-stage process of forging under conventional conditions. On the basis of numerical calculations, this technology is not proven, due to the formation of numerous laps in the finished forging (often two or even three areas). Moreover, mean stress values obtained in this technology would be too high, which prompted the search for a better process of forming.

Another technology analysed was two-stage forging under conventional and isothermal conditions. From the calculations carried out for isothermal forging positive results (no laps in the material) were obtained only for two temperature values: $950^{\circ} \mathrm{C}$ and $1000^{\circ} \mathrm{C}$. The problem in applying this technology is twice the value of mean stress in the 
final stage compared to the same stage carried out under conventional conditions. Twostage forging technology under conventional conditions proved to be the best in terms of the parameters tested, with the following process parameters: lubricant friction factor 0.08 and $50 \%$ initial draft.

Therefore it is concluded that the alloy - and presumably other nickel-based alloys are not recommended for isothermal forging. Appropriate turbine disk forging process design, taking into account the initial processing of the material, shape of auxiliary impressions, lubricants with suitable tribological properties, as well as carefully selected tools and material temperatures produce the final product free of defects.

\section{Acknowledgements}

Financial support of Structural Funds in the Operational Programme - Innovative Economy (IE OP) financed from the European Regional Development Fund - Project No WND-POIG.01.03.01-12-004/09 is gratefully acknowledged.

\section{REFERENCES}

[1] Mikułowski B.: Stopy żaroodporne i żarowytrzymałe - nadstopy, Wydawnictwo AGH, Kraków 1997

[2] Ma Y., Sun J., Xie X., Zhao J., Yan P.: An investigation on fine-grain formation and structural character in cast IN718 superalloy, Journal of Materials Processing Technology 137 (2003), 35-39

[3] Hernas A., Maciejny A.: Żarowytrzymałe stopy metali, Wydawnictwo Zakłady Narodowe im. Ossolińskich, Wrocław 1989

[4] Hernas A.: Żarowytrzymałość stali i stopów, Wydawnictwo Politechniki Śląskiej, Gliwice 1999

[5] Chyta P.: Kucie matrycowe odkuwek o skomplikowanym kształcie ze stopu niklu Inconel 718, AGH Wydział Inżynierii Metali i Informatyki przemysłowej, Kraków 2009, M.Sc. thesis, unpublished

[6] Biel M., Dubiel B., Czyrska-Filemonowicz A.: Monokrystaliczne nadstopy niklu na łopatki turbin gazowych, Hutnik - Wiadomości Hutnicze, 69 (2002) 4, 144-152

[7] Thomas A., El-Wahabi M., Cabrera J.M., Prado J.M.: High temperature deformation of Inconel 718, Material Processing and Technology, 177 (2006), 469-472

[8] SińczakJ., Łukaszek-Sołek A., Bednarek S., Chyła P.: The forging process of aircraft engines turbine blades, Metallurgy and Foundry Engineering, 36 (2010) 2, 83-90

Received

October 2011 